\title{
Lexico-Grammatical Analysis of Yellow-Yellow by Kaine Agary with a Focus on Experiential and Textual Meanings
}

\author{
Leonard A. Koussouhon \\ Full Professor of Applied Linguistics, African and English Literature, English Department, \\ koussouhon@yahoo.com
}

Ashani M. Dossoumou

Ph.D. Candidate at Ecole Doctorale Pluridisciplinaire (EDP), Faculty of Arts and Humanities (FLASH), University of Abomey-Calavi (Bénin). (Laboratory for Research in Linguistics and Literature (LabReLL)) dossoumoumichel@gmail.com,

\section{Doi:10.5901/mjss.2014.v5n23p2430}

\section{Abstract}

The field of Functional Linguistics applied to Anglophone literature goes along with its method of studies which draws on the application of linguistic theories to corpuses. Based on language theories, it can help to analyze, explain, criticize, interpret and even discuss pieces of texts. Among these theories, ranges Systemic Functional Grammar (henceforth SFG) or Systemic Functional Linguistics (hereafter SFL) with regard to the current growing linguistic trend in the field of literary studies. This article seeks to apply the Lexico-grammar theory drawn from SFG or SFL, with a special emphasis on Transitivity and Theme. According to systemic scholars (Halliday, 1971; Eggins, 2004; Halliday and Matthiessen, 2004; and Halliday and Matthiessen, 2006, etc.), the exploration of the Transitivity properties (process types, participants, and circumstances) in/of a text can give a full insight into how the writer encodes experiential meaning therein. They also hold that the analysis of the Theme patterns (topical (or experiential), interpersonal, structural and textual) in/of a text can reveal how its language is organized to embody texture or textual meaning. Given the importance of texture in the making of text, Koussouhon and Allagbe (2013) contend that the analysis of textual meaning can give an insight into the mechanisms that create a meaningful text. By applying the Lexicogrammar theory to one of the new millennium novels, viz., Kaine Agary's Yellow-Yellow (2006), the current article aims to gain a full insight into how the writer encodes her experience (or fictional reality) via the medium of language, on the one hand, and how she organizes her language to achieve this, on the other. Above all, the article aims to prove the relevance of this theory to the reading and interpretation of contemporary Anglophone African prose works.

Keywords: lexico-grammar, process, theme, transitivity, experiential meaning, textual meaning, systemic functional grammar.

\section{Introduction}

Linguistics is the systematic study of language in terms of what it is and how it functions. In The New Encyclopaedia Britannica (1982), it is stated that the field of linguistics may be divided into three dichotomies: Synchronic versus Diachronic, Microlinguistics versus Macrolinguistics, and Theoretical versus Applied. The current article considers applied linguistics which is the cornerstone of Systemic Functional Linguistics (hereafter SFL) developed by M.A.K. Halliday and his followers. Such an application is meant to assess how people use language or how language is structured for use (Eggins, 2004) in a work of art, say, a literary text, and in any text, spoken or written.

This article deals with the lexico-grammatical analysis of the societal and environment-focused extracts culled from the novel Yellow-Yellow (2006). More specifically, the inquiry emphasizes the analysis on two of the three linguistic metafunctions (ideational, textual and experiential). On the one hand, it digs into the grammar of experiential meaning through its material, mental, relational, behavioural, verbal and existential processes, and on the grammar of textual meaning through its topical, structural, interpersonal and textual themes, on the other. Eventually, the application of critical discourse analysis principles to the linguistic description findings will enable to identify the ideology and values underlying the novel under study. 


\section{The Linguistic Metafunctions}

Contrary to Jakobson (1963) who defined six functions of language (conative, expressive, referential, phatic, poetic and metalinguistic), according to which an effective act of verbal communication can be described as linguistic communication, Halliday \& Matthiessen (2004) rather identified three Metafunctions: ideational, interpersonal and textual. But this article rather considers the ideational and textual metafunctions.

$>$ The ideational metafunction construes human experience through language, making sense of "reality". According to Halliday and Matthiessen (2006), it reflects the contextual value of "field", through participant, circumstance and process (material, mental, behavioural, relational, verbal and existential) types. It is viewed as a theory of reality and a resource for reflecting on the world.

$>$ The textual metafunction relates to mode; i.e., the internal organization and communicative nature of a text. It is regarded as an enabling metafunction as it is concerned with organizing ideational and interpersonal meanings as discourse through theme types (Topical, structural, Interpersonal, Textual and multiple).

\section{An Overview of the Grammar of Experiential Meaning and Grammar of Textual Meaning}

\subsection{The Grammar of experiential meaning}

\subsubsection{Material process}

Material processes are processes of doing-and-happening. They have basically to do with some entity doing something or undertaking some action. They are referred to as processes of actions, involving therefore actors or participants.

\subsubsection{Mental processes}

While material clauses are concerned with our experience of the material world, 'mental' clauses are rather concerned with our experience of the world of our own consciousness. They are, according to Halliday \& Matthiessen (2004), clauses of sensing: a 'mental' clause construes a quantum of change in the flow of events taking place in our own consciousness. These processes encode meaning of thinking and feeling. They in actual fact relate to mental reactions: thoughts, feelings and perceptions. Halliday (cited in Eggins, 2004) classifies mental processes into three classes: cognition, affection and perception.

\subsubsection{Relational Processes}

The category of Relational processes covers the many different ways in which "being" can be expressed in English clauses. This specifically provides a rich and complex area of clause transitivity. Relational processes are subdivided into two main categories: Attributive processes and Identifying processes.

\subsubsection{Verbal Processes}

Verbal processes are processes of verbal action: saying and all its many synonyms, including symbolic exchanges of meaning. A verbal process typically contains three participants: Sayer, Receiver and Verbiage.

\subsubsection{Existential processes}

Existential processes represent experience by positing that 'there was/is something'. Existential processes are easily identifiable as the structure involves the use of the word 'there'. There, when used in existential processes, has no representational meaning: it does not refer to a location. Existential processes typically employ the verb be or synonyms such as exist, arise, occur. The only obligatory participant in an existential process which receives functional label is called the Existent.

\subsubsection{Behavioural processes}

Behavioural processes are the "half-way house" between material and mental processes. That is, the meanings they 
realize are mid-way between material and mental. They are in part about action, but that action has to be experienced by a conscious being. Behavioural are typically processes of physiological and psychological behaviour.

\subsection{The Grammar of Textual meaning}

This is the strand of meaning that enables texts to be negotiated. Halliday (1974:95, 97), (cited in Eggins, 1994:273) describes the textual metafunction as the "relevance" or the enabling metafunction. The theme component is the point of departure for the message to be conveyed. It contains familiar or given information. Reflecting the three-dimensional metafunction structure of the clause, systemicists identify three different types of elements of clause structure that can get to be theme: (marked, unmarked and structural) topical or experiential elements, interpersonal elements, and textual elements.

Unmarked topical themes are the most typical/usual themes (subject, finite, Wh-elements) conflating with the Mood structure constituent that typically occurs in first position in clauses of that Mood class.

Marked topical themes signal that all things are not equal, that something in the context requires an atypical meaning to be made. Marked themes conflate with any other constituent from the Mood system.

Structural topical themes are those relative pronouns that occur in subject position after clause boundaries.

Interpersonal themes occur at the beginning of a clause; they are assigned a Mood label (but not a transitivity label). They are commonly: un-fused finite (in interrogative structures), and the Modal adjuncts: Mood, Polarity, Vocative and Comment.

Textual themes are those expressing neither interpersonal nor experiential meaning, but which are doing important cohesive work in relating the clause to its context. There are two types of textual themes, viz. Continuity Adjuncts and Conjunctive Adjuncts.

Structural themes are relative pronouns or Wh-elements which bear neither the position of carrier nor that of topical. They usually occur after the clause boundary.

All in all, the review of the realization of the systems involved in theme network enables to examine the contribution that thematic organization makes to the cohesive development of texts and helps to explain why the textual function of language is referred to as "Enabling Function".

\section{Transitivity and Theme Analyses of the Two Extracts}

We carried out our transitivity and theme analyses on two extracts drawn from Yellow-Yellow (2006). Following Eggins (2004), Koussouhon and Allagbe (2013), Koussouhon and Koukpossi (2013), we first split the extracts into clauses. Then we counted and tabularized the clauses accordingly (see details in appendices).

\subsection{Extract $N^{\circ} 1$}

Table 1: Distribution of process and theme types in extract $\mathrm{N}^{\circ} 1$.

\begin{tabular}{|c|c|c|c|}
\hline \multicolumn{2}{|c|}{ Process types } & \multicolumn{2}{|c|}{ Extract $N^{\circ} 1$} \\
\hline \multicolumn{2}{|c|}{ Material } & 47 & $49.47 \%$ \\
\hline \multicolumn{2}{|c|}{ Mental } & 11 & $11.57 \%$ \\
\hline \multicolumn{2}{|c|}{ Behavioural } & 04 & $04.21 \%$ \\
\hline \multicolumn{2}{|c|}{ Verbal } & 11 & $11.57 \%$ \\
\hline \multicolumn{2}{|c|}{ Existential } & 03 & $03.15 \%$ \\
\hline \multirow{3}{*}{ Relational } & Intensive & 12 & $12.63 \%$ \\
\hline & Possessive & 03 & $03.15 \%$ \\
\hline & Circumstantial & 04 & $04.21 \%$ \\
\hline \multicolumn{2}{|c|}{ Total processes } & 95 & $100 \%$ \\
\hline \multirow{3}{*}{ Topical } & Unmarked & 78 & $50.32 \%$ \\
\hline & Marked & 08 & $05.16 \%$ \\
\hline & Structural & 05 & $03.22 \%$ \\
\hline \multicolumn{2}{|c|}{ Textual } & 34 & $21.93 \%$ \\
\hline \multicolumn{2}{|c|}{ Interpersonal } & 11 & $07.09 \%$ \\
\hline \multicolumn{2}{|c|}{ Structural } & 19 & $12.25 \%$ \\
\hline \multicolumn{2}{|c|}{ Total themes } & 155 & $100 \%$ \\
\hline
\end{tabular}


The table above shows how process and theme types are distributed in/across extract $\mathrm{N}^{\circ} 1$. The transitivity analysis of the extract reveals 47 (i.e., 49.47\%) material processes. This denotes an over-materialization, underpinning the fictional reality in/of the extract. Other process types (mental, behavioural, verbal, existential and relational) with varied proportions enhance this. The theme study of the extract also discloses 91 (i.e., 58.70\%) topical themes. This exudes an over-topicalization, uncovering the issues (for instance, oil slick, women's vulnerability, etc.) addressed in the extract.

\subsection{Critical Discussion of the findings of extract $N^{\circ} 1$}

As the transitivity analysis exudes, extract $\mathrm{N}^{\circ} 1$ contains ninety-five (95) processes. This figure is shared by the six process types propounded by Halliday and Matthiessen (2004). However, two out of the six, viz. Material processes (49.47\%) and relational ones (19.99\%) are most predominant. Another salient characteristic of the extract is that mental and verbal processes have equal proportions. That is, there are 11 (i.e., 11.57\%) mental and verbal processes in the extract.

The number of material processes indicates an over-materialization in/of the text. This is to say, the extract is a highly materialized one; it pinpoints the suffering of the Niger Delta people, especially women, caused by oil spillage and slick. In this passage, the narrator, Zilayefa (also called Yellow-Yellow), recounts her experience of how several hectares of her village farmland get polluted by spilled crude oil. As a result, the pollution causes many environmental and socioeconomic damages to the villagers, including the narrator's mother. The villagers then request through their head of village for compensation from the Oil Company. But the latter refuses to yield to their request and attributes the oil spillage to sabotage perpetrated against it by the youths. This perception is shown in the narrator's use of many transitive and intransitive material processes. Consider, for instance, the processes "ran", "broke" and "spilled" in the subsequent passage from the extract: "During my second to last year in secondary school, one of the crude oil pipes that ran through my village broke and spilled oil over several hectares of land, my mother's farm included." (p. 3)

In fact, this situation affects both the villagers (the narrator included) and the owners of Oil Company psychologically. One can notice this as they voice out their feelings, emotions, pains, etc., and relate with one another and with things in the text. In the following example, mental processes are underlined whereas verbal processes are put in bold. For example, the narrator, after seeing the state of her mother when she returns home from the farm almost voiceless asking for her bathing soap and sponge, says "I was wondering why she needed them, I saw that her legs were stained black. "What happened? I asked. "And bring my towel too", she said, ignoring my question." and adds that "I heard people shouting... some covered from head to toe, was marching to see the Amananaowei, the head of village" to complain to him and ask him to take the issue up with the Oil Company so that the community can get compensation. The owners of the burst pipes defending themselves say "they suspected sabotage by the youths and were not going to pay compensation for all the destruction that the burst pipes had caused." Drawing on the sociocultural and political context within which this narrative is set, one may argue that the oil slick issue is a complex situation likened to a timely bomb which may, at any time, explode in the Niger Delta. Such argumentation is in actual fact emphasised by the theme types in the extract.

The theme analysis of the current passage reveals that it includes 155 themes. Out of this figure, 91 are topical (i.e., 58.70\%) irrespective of whether they are in marked, unmarked or structural positions, 34 textual (i.e., 21.93\%), 19 structural (i.e., 12.25\%) and 11 interpersonal (i.e., 07.09\%). The huge number of topical themes is indicative of an overtopicalization of/in the text. The over-topicalization of the text can be related to the theme of "struggle for the emancipation of Niger Delta people". The Niger Delta people, according to history, have long been marginalized by the Nigerian government in connivance with multinational oil companies that have turned their living environment into unfertile land for planting, their water undrinkable and their air contaminated with gas flaring. These people are still seeking for an answer to the simple but thought-provoking question: how are the ljaws and other ethnic groups suffering and even dying from hunger while the wealth of their soil feeds and enriches others? In the 1990s, this question prompted many activists like Ken Saro-Wiwa, Isaac Adaka Boro into inciting the Ogonis against the then federal government. What this earned them was the wrath of the greedy, selfish, authoritarian, blind and heartless military junta of General Abacha. In fact, Ken Saro-Wiwa and other nine Ogoni kinsmen were executed without a just trial on Friday, 13th of November, 1995. From this text, one can infer that the death of Ken Saro-Wiwa and the others did not put an end to the struggle. The struggle still continues!

In a recent interview with the Nigerian National Life Newspaper on 4th March, 2011, Kaine Agary points out that "The Niger Delta issue is just as complicated as that of all other blessed and oil-resourced regions in Africa. The issue is justice, or, in this case, injustice. When a people feel raped, pillaged and marginalized, there are bound to be problems. Nobody, not even a two-year old child, wants to feel cheated." It follows from this a view that so long as the 
marginalization of the Ogoni people continues there shall be no peace in the land. There shall be a social and interpersonal unrest between the ruling power or the multinational oil companies and the population if the damages made to the latter are not compensated for. This perception is depicted by the interpersonal themes identified in this extract. The 11 interpersonal themes (i.e., 07.09\%) in the text point to the sense of a deep change following the cycle of spillageinduced environmental impacts including the rise in water level, the falling of acid rain and the depletion of animal and plant species in the land. From the numerological perspective, figure seven (07) is symbolic of abundance. When applied to this extract, it (the figure) accounts for the abundance of gas and oil resources in the Niger Delta region. This may equally be construed as the abundant losses incurred by the community.

\subsection{Extract $N^{\circ} 2$}

Table 2: Distribution of process and theme types in extract $N^{\circ} 2$.

\begin{tabular}{|c|c|c|c|}
\hline \multicolumn{2}{|c|}{ Process types } & \multicolumn{2}{|c|}{ Extract $N^{\circ} 2$} \\
\hline \multicolumn{2}{|c|}{ Material } & 44 & $56.41 \%$ \\
\hline \multicolumn{2}{|c|}{ Mental } & 03 & $03.84 \%$ \\
\hline \multicolumn{2}{|c|}{ Behavioural } & 03 & $03.84 \%$ \\
\hline \multicolumn{2}{|c|}{ Verbal } & 07 & $08.97 \%$ \\
\hline \multicolumn{2}{|c|}{ Existential } & 02 & $02.56 \%$ \\
\hline \multirow{3}{*}{ Relational } & Intensive & 10 & $12.82 \%$ \\
\hline & Possessive & 07 & $08.97 \%$ \\
\hline & Circumstantial & 02 & $02.56 \%$ \\
\hline \multicolumn{2}{|c|}{ Total processes } & 78 & $100 \%$ \\
\hline \multirow{3}{*}{ Topical } & Unmarked & 47 & $40.86 \%$ \\
\hline & Marked & 09 & $07.82 \%$ \\
\hline & Structural & 09 & $07.82 \%$ \\
\hline \multicolumn{2}{|c|}{ Textual } & 28 & $24.34 \%$ \\
\hline \multicolumn{2}{|c|}{ Interpersonal } & 08 & $06.95 \%$ \\
\hline \multicolumn{2}{|c|}{ Structural } & 14 & $12.17 \%$ \\
\hline \multicolumn{2}{|c|}{ Total themes } & 115 & $100 \%$ \\
\hline
\end{tabular}

In the table above, the statistics of process and theme types employed in extract $\mathrm{N}^{\circ} 2$ are presented. The transitivity study of the extract exudes 44 (i.e., 56.41\%) material processes. This indicates an over-materialization, underpinning the fictional reality in/of the extract. Other process types (mental, behavioural, verbal, existential and relational) with varied proportions boost this point of view. The theme study of the extract also unveils 65 (i.e., $56.50 \%$ ) topical themes. This exudes an over-topicalization, uncovering the issues (for example, corrupt justice, the freedom of expression, etc.) addressed in the extract.

\subsection{Critical Discussion of the findings of extract $N^{\circ} 2$}

As the transitivity analysis reveals, extract $\mathrm{N}^{\circ} 2$ includes seventy-eight (78) processes. The figure comprises all the six process types propounded by Halliday and Matthiessen (2004). Only two, however, out of the six, viz. Material processes (56.41\%) and relational ones (24.35\%) are the most predominant. Another striking feature of the extract is that mental and behavioural and existential processes share very little proportions. That is, there are 3 (i.e., 03.84\%) mental and behavioural processes in the extract, and $2(02.56 \%)$ existential processes in the extract.

The number of material processes indicates an over-materialization in/of the text. It can be inferred from this that the extract is highly materialized, underscoring the highly corrupt justice system in Nigeria. In this excerpt, the narrator recounts the general experience so far, whereby people do not rely anymore on, or have little confidence in the fairness of justice or court's decisions. The judges have imbibed the culture of corruption to the extent that a case is never quickly adjudicated. Instead, it would be adjourned over and over again until the litigants and their lawyers get the message and pay some bribe to the presiding judge. This perception is shown in the narrator's use of many transitive and intransitive material processes. Consider, for example, the processes "would be adjourned", "got" "paid" and "acted" in the subsequent passage from the extract: "The judges were so corrupt that a simple case would be adjourned over and over again until the litigants and their lawyers got the message and paid some bribe to the judge. Whoever acted quicker 
received a judgment in their favor. Such was the way of the justice system." This appalling situation of the judiciary system in actual fact frustrates the people. Because of protracted frustration, the people lose interest and confidence in the justice system of their country (Nigeria).

The theme analysis of this excerpt reveals that it includes 115 themes. Out of this figure, 65 are topical (i.e., $56.50 \%$ ) irrespective of whether they are in marked, unmarked or structural positions, 28 textual (i.e., 24.34\%), 14 structural (i.e., 12.17\%) and 08 interpersonal (i.e., 06.95\%). The preponderant number of topical themes is indicative of an over-topicalization of/in the text. This over-topicalized extract can be related mainly to the themes of "freedom of expression" and "corrupt judicial system". The judiciary appears as the custodian of justice. But, owing to the rampant corruption of some Nigerian, people's reaction attempts to damn and ridicule the country's judicial system. This perception is depicted by the paucity of interpersonal, behavioural and existential themes identified in this extract. The 8 interpersonal themes (i.e., $06.95 \%$ ) in the text point to the negative vibration propounded by the corrupt mindset of the judiciary officers. This token number reveals a lack of sound interpersonal relationships that undermine democracy. Moreover, the moral decay of the justice definitely subverts the rule of law which is the basis of every civilized society. As a result, the whole development fabric and the country's reputation have become true challenges. This thus implies that the Nigerian Judiciary's cup is half empty with respect to integrity.

Obviously, the majority of Nigerians are tired of their corrupt judicial system. Their earnest expectation is undoubtedly to see a "Naira-land" where the guilty pay effectively for their crimes and the innocent walk freely with their heads high. Knowing that the corrupt justice has decayed the overall system of the nation, it is high time all those who love truth and justice, all those who cherish freedom and fairness, equity and transparency, be they learned or unlearned, rose up together not as crude folks but as noble and intelligent beings in order to stamp out that under-developmentprovoking scourge in the country.

\section{Summary and Conclusion}

The very target of this article was to gain an insight into how meanings are encoded in the novel Yellow-Yellow, drawing on SFL. This analysis based on the grammar of experiential and textual meanings has explored the power of grammar (the powerhouse of language) at work to embed and create meanings. Thereafter, an overview of the principles guiding the above-conducted lexico-grammatical analysis, with a focus on the experiential and textual strand of meanings through the process and theme types, has set the stage for the practical analysis. This was followed by the practical analysis of the two extracts under study. The critical, interpretive discursive processes might actually confirm, with additional emphasis and a sharpening of focus, the findings of common sense.

As for the novel Yellow-Yellow, the linguistic description and discussion of its salient features (topical themes, material processes, a blend of extradiegetic, intradiegetic and hypodiegetic narrative, the overriding use of deitic "the" and personal pronoun "I, me") have served as a backdrop for this article to come up with the mind that the essential feature of literary extracts is interaction; i.e., the exchange of meanings. Also, a piece of writing in fiction is not only a product of its environment but also functions in that environment. Eventually, the ideology sustaining Yellow-Yellow is oriented towards building a redoubtable social, environment-friendly and judicial model that will guarantee fairness, equity and transparency, the type that will provide true oversight for emancipation and social justice. By focusing on experiential and textual metafunctions, this article places the Nigerian new millennium novelists such as K. Agary in a good position to reconstruct the past and the present in proper perspectives in order to project the future of their nation. As such, it has contributed to shaping the readers' ability to produce some position papers such as literary criticism, review and write-up on the new millennium writers whose ambition is to address the contemporary and topical scourges undermining and hampering the development of their nation in order not to end up irrelevant vis-à-vis their readership.

\section{References}

Agary, K. (2006). Yellow-Yellow. First Edition. Sabo, Yaba, Lagos: Dtalkshop

Akung, J. E. (2012): "New Historicist Dimensons in Helon Habila's Measuring Time". In International Journal of Applied Linguistics \& English Literature, Vol. 1, N 4, pp 144-151.

Ayoola, M. O. (2013): "An Interpersonal Metafunction Analysis of some selected Political Advertisements in Some Nigerian Newspapers". In International Journal of Humanities and Social Science, Vol. 3, № 8, pp 165-178.

Eggins, S. (2004, 2nd ed.): An Introduction to Systemic Functional Linguistics. Great Britain: Continuum.

Encyclopedia Britannica (1982): The New Encyclopedia Britannica, 15th Edition. UK: Encyclopedia Britannica (UK) Ltd.

Fairclough, I. \& N. (2012): Political Discourse Analysis. USA and Canada: Routledge.

Fairclough, N. (2003): Analysing Discourse: Textual analysis for social research. London and New York: Routledge. 
Fontaine, L. (2013): Analysing English Grammar: A Systemic Functional Introduction. New York: Cambridge University Press.

Halliday, M.A.K. \& Matthiessen Ch. (2004, third edition): An Introduction to Functional Grammar, London: Hodder Education, and Hachette UK Company.

Halliday, M.A.K. \& Matthiessen Ch. (2006): Construing Experience Through Meaning: A Language-based Approach to Cognition. London - New York: Continuum.

Koussouhon, L. \& Allagbe, A. A. (2013): The Lexicogrammar of Chimamanda Ngozi Adichie' fiction: A systemic functional contribution. In Langage \& Devenir $N^{\circ} 22,1^{\text {er }}$ semestre 2013, pp 19-44.

Koussouhon, L. \& Koukpossi, A. (2013): "Analyse lexico-grammaticale du discours d'investiture de François Hollande avec un accent spécial sur la transitivité". In Revue Togolaise des Sciences, Vol 7, № 1, pp 353-372.

Rimmon-Kenan, Sh. (1983): Narrative Fiction: Contemporary Poetics. London and New- York: Methuen.

Young, L. \& Harrison C. (2004): Systemic Functional Linguistics and Critical Discourse Analysis, studies in social change. London and New York: Continuum.

\section{Appendices}

\section{Lexicogrammatical Analyses}

Keys: The Transitivity analysis has been carried out for each extract according to the keys presented below.

$\mathrm{P}=$ process; $\mathrm{Pm}=$ material; $\mathrm{Pme}=$ mental; $\mathrm{Pb}=$ behavioural; $\mathrm{Pv}=$ verbal; $\mathrm{Pe}=$ existential; $\mathrm{P} i=$ intensive; $\mathrm{Pcc}=$ circumstantial; $\mathrm{Pp}=$ possessive; $\mathrm{Pc}=$ causative; $A=$ actor; $G=$ goal; $B=$ beneficiary; $R=$ range; $S=$ senser; $P h=$ phenomenon; Sy= sayer; Rv= receiver; Vb= verbiage; $X=$ existent; $T=$ token; $V=$ value; $\mathrm{Cr}=$ carrier; $\mathrm{At}=$ attribute; $\mathrm{Pr}=$ possessor; $\mathrm{Pd}=$ possessed; $\mathrm{C}=$ circumstance; $\mathrm{Cl}=$ location; $\mathrm{Cx}=$ extent; $\mathrm{CM}=$ manner; $\mathrm{Cc}=$ cause; $\mathrm{Ca}=$ accompaniment; $\mathrm{Ct}=$ matter; $\mathrm{Co}=$ role; $\mathrm{Ag}=$ agent; $\mathrm{Be}=$ behaver; $\mathrm{Bh}=$ behavior.

\section{Transitivity Analysis}

I. Extract $n^{\circ} 1$

During my second to last year in secondary school $(\mathrm{Cl})$, one of the crude oil pipes that $(\mathrm{A})$ ran $(\mathrm{Pm})$ through my village $(\mathrm{Cl})$ broke $(\mathrm{Pm})$ and spilled $(\mathrm{Pm})$ oil $(\mathrm{G})$ over several hectares of land $(\mathrm{Cl})$, my mother's farm $(\mathrm{Cr})$ included $(\mathrm{At})$. I ( $\mathrm{Cr}$ ) was (Pi) at home $(\mathrm{At} / \mathrm{Cl})$ that day $(\mathrm{Cl})$ when she $(\mathrm{A})$ returned $(\mathrm{Pm})$ shortly $(\mathrm{Cm})$ after $(\mathrm{Cl})$ leaving $(\mathrm{Pm})$ for the farm $(\mathrm{Cl})$. When she $(\mathrm{A})$ got to $(\mathrm{Pm})$ the house $(\mathrm{Cl})$, she $(A)$ knocked $(\mathrm{Pm})$ on the door $(\mathrm{Cl})$ (and (she) (sy) said (Pv) very coolly (Cm), ["Zilayefa, bring (Pm) me (B) my bathing soap and sponge (G)."] (vb) As I (S) was wondering (Pme) why (cc) she (Cr/pr) needed (Pp) them (At/pd), I (s) saw (Pme) [that her legs (G) were stained black (Pm)] (ph).

["What (A) happened (Pm)?"] vb I (sy) asked (Pv).

["And bring (Pm) my towel (G) too"] (vb), she (sy) said (Pv), ignoring (Pme) my question (ph).

["What $(A)$ happened $(\mathrm{Pm})$ ?"] $(\mathrm{vb})$ There was $(\mathrm{Pe})$ more urgency $(\mathrm{x})$ in my voice $(\mathrm{Cl})$ as I $(\mathrm{A})$ touched $(\mathrm{Pm})$ her $(\mathrm{R})$ and looked over $(\mathrm{Pb})$ every part of her body $(\mathrm{ph})$. My heart $(\mathrm{A})$ was pounding $(\mathrm{Pm})$ against my chest $(\mathrm{Cl})$ as I $(\mathrm{A})$ tried to imagine (Pme) [what could have happened $(\mathrm{Pme})$ that $(\mathrm{Ag})$ left $(\mathrm{Pc})$ her (cr) void of words (At)] (ph). My mother $(\mathrm{A})$ never $(\mathrm{Cx})$ fought $(\mathrm{Pm})$, and she $(\mathrm{cr})$ did not look like $(\mathrm{Pi})$ she $(\mathrm{G})$ was injured $(\mathrm{Pm})$ in any way $(\mathrm{Cm})$, but when she (cr) was (Pi) upset (At), she ( $\mathrm{Cr})$ got (Pi) very $(\mathrm{Cm})$ quiet (At).

["Oil, Zilayefa,"](vb) she (sy) said (Pv), and turned away (Pm) from (Cl) me, walking (Pm) towards the river (Cl). My mother (sy) hardly ever (Cx) called (Pv) me (Rv) Zilayefa (vb); she (sy) called (Pv) me (Rv) Yellow-Yellow (vb), like everybody else (Cm).

["Oil? From where?"] (ph) I (A) was walking (Pm) behind her (Cl), and then I (s) heard (Pme) [people (Sy) shouting (Pv)] (ph).

[A group of people (cr), painted (At) in the same black as my mother $(\mathrm{Cm})$, some $(\mathrm{cr})$ covered (At) from head to toe (Cl)], was marching $(\mathrm{Pm})$ to see (Pme) the Amananaowei, the head of village] (ph). I (A) joined (Pm) them (G) to find out (Pb) [what (A) had happened (Pm)](ph). It (Cr) turned out (Pi) [some of them $(\mathrm{A})$ had also lost $(\mathrm{Pm})$ their farmland $(\mathrm{G})$ that day $(\mathrm{Cl})](\mathrm{At})$. They $(\mathrm{A})$ were marching $(\mathrm{Pm})$ to the Amananaowei's house $(\mathrm{Cl})$ [ $[\mathrm{to}$ report $(\mathrm{Pv})$ the matter $(\mathrm{vb})$ and demand $(\mathrm{Pb})$ [that he $(\mathrm{A})$ take $(\mathrm{Pm})$ it $(\mathrm{G})$ up $(\mathrm{Cl})$ with the oil company $(\mathrm{Cm})](\mathrm{ph})]$ ] $(\mathrm{Cc})$. Some $(\mathrm{Be})$ were crying $(\mathrm{Pb})$, others (sy) were talking (Pv) about compensation (Ct).

I (A) left (Pm) them (G) and ran (Pm) to my mother's farmland (Cl). It (Cr) was (Pi) the first time (At) I (s) saw (Pme) [what (At) crude oil (Cr) looked like $(\mathrm{Pi})](\mathrm{ph})$. I (Be) watched $(\mathrm{Pb})$ [as the thick liquid $(\mathrm{A})$ spread out $(\mathrm{Pm})$ ] $(\mathrm{Cl})$, covering $(\mathrm{Pm})$ more land $(\mathrm{G})$ and drowning $(\mathrm{Pm})$ small animals $(\mathrm{G})$ in its path $(\mathrm{Cl})$. It $(\mathrm{A})$ just kept spreading $(\mathrm{Pm})$ and I $(\mathrm{s})$ wondered $(\mathrm{Pme})$ if it $(\mathrm{A})$ would stop $(\mathrm{Pm})$, when $(\mathrm{Cl})$ it $(\mathrm{A})$ would stop $(\mathrm{Pm})$, how far $(\mathrm{Cl})$ it $(\mathrm{A})$ would spread $(\mathrm{Pm})$. Then there was $(\mathrm{Pe})$ the smell $(\mathrm{x})$. I (A) can't describe $(\mathrm{Pm})$ it $(\mathrm{G})$ but it (Cr) was (pi) strong (At)- so strong (At) it (Ag/attributor) made (Pc)my head (cr) hurt (At) and turned $(\mathrm{Pm})$ my stomach $(\mathrm{G})$. I ( $\mathrm{A} / \mathrm{Be})$ bent $(\mathrm{Pm})$ over $(\mathrm{Cm})$, and retched $(\mathrm{Pb})$ so hard $(\mathrm{Cm})$ I $(\mathrm{Cr})$ became $(\mathrm{Pi})$ dizzy $(\mathrm{At})$. It $(\mathrm{Cr})$ felt $(\mathrm{Pi})$ [like everything $(\mathrm{Cr})$ had turned to $(\mathrm{Pi})$ black $(\mathrm{At})](\mathrm{At})$ and was spinning $(\mathrm{Pm})$ around me $(\mathrm{Cl})$. There was $(\mathrm{Pe})$ so much oil $(\mathrm{x})$, and we $(\mathrm{A})$ could do $(\mathrm{Pm})$ nothing $(\mathrm{G})$ with it- [viscous oil $(\mathrm{M})$ that would not dry out $(\mathrm{Pm})$, black oil that $(\mathrm{Cr})$ was $(\mathrm{Pi})$ knee-deep $(\mathrm{At})](\mathrm{Cm})$. I (A) stayed $(\mathrm{Pm})$ there $(\mathrm{Cl})$, in a daze $(\mathrm{Cm})$, until someone (sy) shouted (Pv) at me (Rv), ["You (A) no go commot (Pm) for there (Cl)? You (Cr) dey look like (Pi) na beta tin (At)! Come on (Pm), leave (Pm) dat place (Cl)!! $](\mathrm{vb})$

The community (A) took $(\mathrm{Pm})$ the matter $(\mathrm{G})$ up $(\mathrm{Cm})$ with the oil company that $(\mathrm{T} / \mathrm{pr})$ owned $(\mathrm{Pp})$ the pipes $(\mathrm{V} / \mathrm{pd})$, but they (sy) said (Pv)[they (s) suspected $(\mathrm{Pme})$ sabotage by the youths $(\mathrm{ph})$ ] $(\mathrm{vb})$ and were not going to pay $(\mathrm{Pm})$ compensation $(\mathrm{R})$ [for all the destruction that $(\mathrm{V})$ the burst pipes $(\mathrm{T})$ had caused $(\mathrm{pc})]$ (Ccc). And so it (Cr) was (Pi) that, in a single day (Cl), [my mother (A) lost (Pm) her main source of sustenance (G)] (At). However, I (s) think $(\mathrm{Pme})$ [she (T/pr) had lost (Pp) that land (V/pd) a long time ago (Cl)], because (Cc) each season (T) yielded (pcc) less than the season before (V). Not unlike the way $(\mathrm{Cm})$ she and others in the village $(\mathrm{T} / \mathrm{pr})$ had gradually $(\mathrm{Cm})$ lost $(\mathrm{Pp})$, year after year $(\mathrm{Cl})$, the creatures of the river to oil spills, acid rain, gas flares $(\mathrm{V} / \mathrm{pd})$, and who (s) knows (Pme) what else (ph), according to the voices on the radio.

Extract $n^{\circ} 2$

Many people $(\mathrm{A})$ did not read $(\mathrm{pm})$ newspapers $(\mathrm{G})$, as the general feeling $(\mathrm{Cr})$ was (pi) [that the newspapers $(\mathrm{G})$ were packed $(\mathrm{pm})$ with lies $(\mathrm{Cm})$ ] (At) because (Cc)any journalist who (Cr/pr) had (pp) the gall (At/pd)to print (pm) antigovernment stories (G) was carted away (pm) and locked up (pm) for their gumption (Cc). Therefore, the news mainly centered around $(\mathrm{pm})$ which human rights activist $(\mathrm{G})$ had been arrested $(\mathrm{pm})$, what political figure $(\mathrm{G})$ had been assassinated (pm) or "killed (pm) by armed robbers (A)," and the new international policy against Nigeria (G). However, as long as the world (A) was still buying (pm) Nigeria's oil $(G)$, our head of state $(\mathrm{s})$ did not care (pme) [from which international Union we $(G)$ were suspended (pm) for human rights abuses (CC)] (Cl).

Lagos bus stop (Cr) was (pi) the centre of news (At) in the city $(\mathrm{Cl})$. If you $(\mathrm{A})$ missed $(\mathrm{pm})$ a paper $(\mathrm{G})$ a day or two before $(\mathrm{Cl})$, you $(\mathrm{A})$ could go $(\mathrm{pm})$ to Lagos bus stop $(\mathrm{Cl})$ and find $(\mathrm{pm})$ the paper $(\mathrm{G})$ there $(\mathrm{Cl})$. At Lagos bus stop $(\mathrm{Cl})$, the newspaper vendors $(\mathrm{A})$ spread out $(\mathrm{pm})$ their many 
newspapers and magazines $(\mathrm{G})$ on makeshift display stands $(\mathrm{Cl})$; if they $(\mathrm{Cr} / \mathrm{pr})$ ran out $(\mathrm{pp})$ of space $(\mathrm{At} / \mathrm{pd})$ on these stands $(\mathrm{Cl})$, they $(\mathrm{A})$ 'd use $(\mathrm{pm})$ [plastic sheets $(\mathrm{G})$ thrown $(\mathrm{pm})$ on the dirty road $(\mathrm{Cl})](\mathrm{G})$.

Though the vendors $(\mathrm{A})$ allowed $(\mathrm{pm})$ passersby $(\mathrm{G})$ to go $(\mathrm{pm})$ through the daily papers $(\mathrm{Cl})$ without paying $(\mathrm{Cm})$, I (s) suspected (pme) [they $(\mathrm{Cr} / \mathrm{pr})$ had $(\mathrm{pp})$ a way of making money $(\mathrm{At} / \mathrm{pd})$ [because they $(\mathrm{Cr})$ were (pi) there $(\mathrm{At} / \mathrm{Cl})$ day in and day out $(\mathrm{Cl})$, with the latest papers $(\mathrm{Cm})](\mathrm{Cc})](\mathrm{ph}) . \mathrm{I}(\mathrm{s})$ doubt (pme) [they $(\mathrm{Cr})$ were (pi) there $(\mathrm{At} / \mathrm{Cl})$ solely $(\mathrm{Cm})$ for the altruistic purpose of disseminating information to the masses $(\mathrm{Cc})](\mathrm{ph})$. Some people $(\mathrm{A})$ bought $(\mathrm{pm})$ the newspapers $(\mathrm{G})$, but [those who $(\mathrm{A})$ did not $(\mathrm{pm})](\mathrm{Cr})$ were $(\mathrm{pi})$ far more numerous (At). They $(\mathrm{A})$ milled $(\mathrm{pm})$ around the vendors $(\mathrm{Cl})$ to soak in (pm) as much information as possible $(\mathrm{G})$ and even debate and analyse (pm) some of the headlines (G). Most of them (sy) spoke (pv) [as though they $(\mathrm{Cr} / \mathrm{pr})$ had $(\mathrm{pp})$ doctorate degrees $(\mathrm{At} / \mathrm{pd})$ in politics $(\mathrm{Cl})](\mathrm{Cl})$, and all of them $(\mathrm{Cr} / \mathrm{pr})$ had $(\mathrm{pp})$ a solution $(\mathrm{At} / \mathrm{pd})$ for Nigeria's problems (Cc);:,:. . None of them $(\mathrm{Be})$ gave $(\mathrm{pb})$ the impression [that they (Cr) felt (pi) threatened (At) by the imminent danger that $(\mathrm{A})$ hung over $(\mathrm{pm})$ their heads $(\mathrm{G})$ ] $(\mathrm{ph})$, due to their loud criticisms of government $(\mathrm{Cc})$. But maybe security operatives $(\mathrm{Be})$ regard $(\mathrm{pb})$ them $(\mathrm{ph})$ as harmless $(\mathrm{Cm})$ in the grand scheme of things $(\mathrm{Cl})$, as they (A) never disappeared $(\mathrm{pm})$ but were $(\mathrm{pi})$ always $(\mathrm{Cx})$ there $(\mathrm{At} / \mathrm{Cl})$ to share $(\mathrm{pm})$ their opinion $(\mathrm{G})$ with anyone passing by $(\mathrm{Ca})$.

[What $(\mathrm{Cr})$ was (pi) certain $(\mathrm{At})](\mathrm{Cr})$ was (pi) that if you (s) wanted (pme) to spread (pm) a rumour $(\mathrm{G})$ with the greatest speed and the widest coverage $(\mathrm{Cm})$, you $(\mathrm{Cr} / \mathrm{pr})$ needed $(\mathrm{pp})$ only $(\mathrm{Cx})$ to whisper $(\mathrm{pv})$ the story $(\mathrm{vb})$ to someone $(\mathrm{Rv})$ at Lagos bus stop $(\mathrm{Cl})$. The rumour $(\mathrm{Cr})$ was $(\mathrm{pi})$ guaranteed (At) to take on $(\mathrm{pm})$ a life of its own $(\mathrm{G})$ and reach $(\mathrm{pm})$ all corners of Port Harcourt $(\mathrm{G})$ within hours $(\mathrm{Cx})$, as Lagos bus stop (T) was (pi) also the oldest central terminal for buses and taxis going to different parts of Port Harcourt $(V)$.

There was (pe) fighting between neighbours, between friends, between communities $(\mathrm{X})$. Things $(\mathrm{Cr})$ were (pi) such (At) that, with frustration weighing $(\mathrm{pm})$ heavily $(\mathrm{Cm})$ on everyone $(\mathrm{G})$, even those who $(\mathrm{Be})$ prided $(\mathrm{pb})$ themselves $(\mathrm{ph})$ on being easygoing and having no enemies $(\mathrm{Cm})$ were dragged (pm) into miniwars (Cl). [Everyone who (A) could afford (pm) it(G)] (Cr/pr) had (pp) their own little army (At/pd) they (A) could call on (pm) to fight $(\mathrm{pm})$ their wars $(\mathrm{G})$, which $(\mathrm{Cr})$ were (pi) over property, contracts, even girlfriends (At). And [the young boys who (T) made up (pi) these armies (V)] were so caught up (pm) in the anarchy $(\mathrm{Cm})$ that they (Cr/pr) lost (pp) all sense of decency and respect (At/pd).

People (s) did not call (pv) the police (Rv) to settle (pm) disputes (G), and even [on those rare occasions when they (A)did (pm) and a matter (G) was charged $(\mathrm{pm})$ to court $(\mathrm{Cl})](\mathrm{Cl})$, there was $(\mathrm{pe})$ so little confidence $(\mathrm{X})$ in the fairness of justice $(\mathrm{Cl})$ that very few $(\mathrm{A})$ waited for $(\mathrm{pm})$ the court's decision $(\mathrm{G})$. The judges ( $\mathrm{Cr}$ ) were (pi) so (Cx) corrupt (At) that a simple case (G) would be adjourned (pm) over and over (Cm) again until the litigants and their lawyers (Cr/pr) got (pp) the message (At/pd) and paid (pm) some bribe $(\mathrm{G})$ to the judge $(\mathrm{B})$. Whoever $(\mathrm{A})$ acted $(\mathrm{pm})$ quicker $(\mathrm{Cm})$ received $(\mathrm{pm})$ a judgment $(\mathrm{G})$ in their favour $(\mathrm{Cm})$. Such $(\mathrm{T})$ was (pi) the way of the justice system $(\mathrm{V})$.

II. Theme analysis

Extract $n^{\circ} 1$

During my second to last year in secondary school (Marked topical Theme), one of the crude oil pipes (Unmarked Topical Theme) that (structural / Topical Theme) ran through my village broke and (Textual Theme) spilled oil over several hectares of land, my mother's farm included. I (Topical Theme) was at home that day (Marked Topical) when (Structural Theme) she (Unmarked Topical Theme) returned shortly after leaving for the farm. When (Structural Theme) she (Unmarked topical theme) got to the house, she (Unmarked Topical Theme) knocked on the door (Rheme) and (Textual Theme) (she) said very coolly, "Zilayefa, (Interpersonal Theme) bring (Unmarked Topical Theme) me my bathing soap and (Textual Theme) sponge." As (Textual Theme) I (Unmarked Topical Theme) was wondering why (Structural Theme) she (Unmarked topical theme) needed them, I (Unmarked topical theme) saw that (Structural Theme) her legs (Unmarked topical theme) were stained black.

"What (Unmarked topical theme) happened?" I (Marked Topical Theme) asked.

"And (Textual Theme) bring (Unmarked topical theme) my towel too", she (Unmarked topical theme) said, ignoring my question.

"What (Unmarked topical theme) happened?" There (Marked Topical Theme) was more urgency in my voice as (Textual Theme) I (Unmarked topical theme) touched her and (Textual Theme) looked over every part of her body. My heart (Unmarked topical theme) was pounding against my chest as (Textual Theme) I (Marked Topical Theme) tried to imagine what (Structural Theme) could have happened that (Structural Topical Theme) left her void of words. My mother (Marked Topical Theme) never fought, and (Textual Theme) she (Unmarked topical theme) did not look like she (Unmarked topical theme) was injured in any way, (Interpersonal Theme) but (Textual Theme) when (Structural Theme) she (Unmarked topical theme) was upset, she (Unmarked topical theme) got very quiet.

"Oil, Zilayefa, (Interpersonal Theme)" she (Unmarked topical theme) said, and (Textual Theme) turned away from me, walking towards the river. My mother (Marked topical theme) hardly ever called me Zilayefa; she (Unmarked topical theme) called me Yellow-Yellow, like (Textual Theme) everybody else (Unmarked topical theme).

"Oil? (Marked topical theme) From where (Structural Theme)?" I (Marked topical theme) was walking behind her, and (Textual Theme) then (Textual Theme) I (Unmarked topical theme) heard people shouting.

A group of people, painted in the same black (Marked topical theme) as (Textual Theme) my mother, some (Unmarked topical theme) covered from head to toe, was marching to see the Amananaowei, the head of village. I (Marked topical theme) joined them to find out what (Structural Theme) had happened. It (Marked topical theme) turned out some of them (Unmarked topical theme) had also lost their farmland that day (Unmarked topical theme). They (Marked topical theme) were marching to the Amananaowei's house to report the matter and (Textual Theme) demand that (Structural Theme) he (Unmarked topical theme) take it up with the oil company. Some (Marked topical theme) were crying, others (Unmarked topical theme) were talking about compensation.

I (Marked topical theme) left them and (Textual Theme) ran to my mother's farmland. It (Marked topical theme) was the first time I (Unmarked topical theme) saw what (Structural Theme) crude oil (Unmarked topical theme) looked like. I (Marked topical theme) watched as (Textual Theme) the thick liquid (Unmarked topical theme) spread out, covering more land and (Textual Theme) drowning small animals in its path. It (Marked topical theme) just (Interpersonal Theme) kept spreading and (Textual Theme) I (Unmarked topical theme) wondered if it would stop, when (Structural Theme) it (Unmarked topical theme) would stop, how far (Structural Theme) it (Unmarked topical theme) would spread. Then (Textual Theme) there (Unmarked topical theme) was the smell. I (Marked topical theme) can't describe it but (Textual Theme) it (Unmarked topical theme) was strong- so (Interpersonal Theme) strong (Textual Theme) it (Unmarked topical theme) made my head hurt and (Textual Theme) turned my stomach. I (Marked topical theme) bent over, and (Textual Theme) retched so (Interpersonal theme) hard I (Unmarked topical theme) became dizzy. It (Marked topical theme) felt like (Textual Theme) everything (Unmarked topical theme) had turned to black and (Textual Theme) was spinning around me. There (Marked topical theme) was so much oil, and (Textual Theme) we (Unmarked topical theme) could do nothing with it - viscous oil (Unmarked topical theme) that (Structural / Topical Theme) would not dry out, black oil that (Structural / Topical Theme) was knee-deep. I (Marked topical theme) stayed there, in a daze, ((Unmarked topical theme)) until someone (Unmarked topical theme) shouted at me, "You no go (Interpersonal Theme) commot for there? You dey (Marked topical theme) look like (Textual Theme) na beta tin! Come on, (Interpersonal Theme) leave dat place!"

The community (Marked topical theme) took the matter up with the oil company that (Structural / Topical Theme) owned the pipes, but (Textual Theme) they (Unmarked topical theme) said they (Unmarked topical theme) suspected sabotage by the youths and (Textual Theme) were not going to pay compensation for all the destruction that (Structural Theme) the burst pipes (Unmarked topical theme) had caused. And (Textual Theme) so (Textual 
Theme) it (Unmarked topical theme) was that, in a single day, (Marked Topical Theme) my mother (Unmarked topical theme) lost her main source of sustenance. However, (Textual Theme) I think (Interpersonal Theme) she (Unmarked topical theme) had lost that land a long time ago (Marked topical theme), because (Textual Theme) each season (Unmarked topical theme) yielded less than the season before. Not unlike (Interpersonal Theme) the way she and others in the village (Unmarked topical theme) had gradually lost, year after year, (Marked Topical Theme) the creatures of the river to oil spills, acid rain, gas flares, (Unmarked topical theme) and (Textual Theme) who (Structural Theme) knows what else, (Structural Theme) according to the voices on the radio.

\section{Extract $n^{\circ} 2$}

Many people (Unmarked Topical theme) did not (Interpersonal theme) read newspapers, as (Textual Theme) the general feeling (Unmarked Topical theme) was that (Structural theme) the newspapers (Unmarked Topical theme) were packed with lies because any journalist (Unmarked Topical theme) who (Structural / Topical theme) had the gall to print antigovernment stories was carted away and (Textual theme) locked up for their gumption. Therefore, (Textual theme) the news (Unmarked Topical theme) mainly (Interpersonal theme) centered around which (Structural theme) human rights activist (Unmarked Topical theme) had been arrested, what (Structural theme) political figure (Unmarked Topical theme) had been assassinated or "killed by armed robbers," and (Textual theme) the new international policy against Nigeria. However, (Textual theme) as long as(Textual Theme) the world (Unmarked Topical theme) was still buying Nigeria's oil, our head of state (Unmarked Topical theme) did (Interpersonal theme) not care from which (Structural theme) international Union we (Unmarked Topical theme) were suspended for human rights abuses.

Lagos bus stop (Marked Topical theme) was the centre of news in the city. If you (Unmarked Topical theme) missed a paper a day or two before, you (Unmarked Topical theme) could go to Lagos bus stop and (Textual theme) find the paper there. At Lagos bus stop, (Marked Topical theme) the newspaper vendors (Unmarked Topical theme) spread out their many newspapers and magazines on makeshift display stands; if they (Unmarked Topical theme) ran out of space on these (Structural theme) stands, they (Unmarked Topical theme)'d use plastic sheets thrown on the dirty road.

Though the vendors (Unmarked Topical theme) allowed passersby to go through the daily papers without paying, I (Unmarked Topical theme) suspected they (Unmarked Topical theme) had a way of making money because they (Unmarked Topical theme) were there day in and (Textual theme) day out, with the latest papers. I (Unmarked Topical theme) doubt they (Unmarked Topical theme) were there solely (Interpersonal theme) for the altruistic purpose of disseminating information to the masses. Some people (Unmarked Topical theme) bought the newspapers, but (Textual theme) those (Unmarked Topical theme) who (Structural /Topical theme) did (Interpersonal theme) not were far more numerous. They (Unmarked Topical theme) milled around the vendors to soak in as much information as possible and (Textual theme) even (Textual theme) debate and analyse some of the headlines. Most of them (Marked Topical theme) spoke as though (Textual theme) they (Unmarked Topical theme) had doctorate degrees in politics, and (Textual theme) all of them (Marked Topical theme) had a solution for Nigeria's problems. None of them (Marked Topical theme) gave the impression that (Structural theme) they (Unmarked Topical theme) felt threatened by the imminent danger (Unmarked Topical theme) that (Structural/Topical theme) hung over their heads, due to their loud criticisms of government. But (Textual theme) maybe (Interpersonal theme) security operatives (Unmarked Topical theme) regard them as harmless in the grand scheme of things, as they (Unmarked Topical theme) never disappeared but (Textual theme) were always there to share their opinion with anyone passing by.

[What (Structural Topical theme) was certain] (Unmarked topical theme) was that (Structural theme) if you (Unmarked Topical theme) wanted to spread a rumour with the greatest speed (Marked Topical) and (Textual theme) the widest coverage, you (Unmarked Topical theme) needed only to whisper the story to someone at Lagos bus stop. The rumour (Unmarked Topical theme) was guaranteed to take on a life of its own and (Textual theme) reach all corners of Port Harcourt within hours, as (Textual theme) Lagos bus stop (Marked Topical theme) was also the oldest central terminal for buses and taxis going to different parts of Port Harcourt.

There (Unmarked Topical theme) was fighting between neighbors, between friends, between communities. Things (Unmarked Topical theme) were such that (Structural theme), with frustration weighing heavily on everyone, (Marked Topical theme) even those (Structural theme) who (Structural / Topical theme) prided themselves on being easygoing and (Textual theme) having no enemies were dragged into miniwars. Everyone (Unmarked Topical theme) who (Structural /Topical theme) could afford it had their own little army they (Unmarked Topical theme) could call on to fight their wars, which (Structural/Topical theme) were over property, contracts, even girlfriends. And (Textual theme) the young boys (Unmarked Topical theme) who (Structural/Topical theme) made up these (Structural theme) armies were so (Textual theme) caught up in the anarchy that (Structural theme) they (Unmarked Topical theme) lost all sense of decency and (Textual theme) respect.

People (Unmarked Topical theme) did not (Interpersonal theme) call the police to settle disputes, and (Textual theme) even on those rare occasions (Marked Topical theme) when (Structural theme) they (Unmarked Topical theme) did (Interpersonal theme) and (Textual theme) a matter (Unmarked Topical theme) was charged to court, there (Unmarked Topical theme) was so (Textual theme) little confidence in the fairness of justice that (Structural theme) very few (Unmarked topical theme) waited for the court's decision. The judges (Unmarked Topical theme) were so (Textual theme) corrupt that (Structural theme) a simple case (Unmarked topical theme) would be adjourned over and (Textual theme) over again until the litigants and their lawyers got the message and (Textual theme) paid some bribe to the judge. Whoever (Structural/Topical theme) acted quicker received a judgment in their favor. Such (Unmarked Topical theme) was the way of the justice system. 